\author{
S.O. Yuryev ${ }^{1}$, S.I. Yushchuk ${ }^{1}$, V.V. Moklyak ${ }^{2}$, F.M. Gonchar ${ }^{1}$, \\ O.M. Gorina ${ }^{1}$, B.B. Onyskiv ${ }^{3}$
}

\title{
Peculiarities of Crystal Structure and Superfine Interactions in Alloys Ti-Co-Sn
}

\author{
${ }^{1}$ Lviv Polytechnic National University, Lviv, Ukraine, s.o.yuryev@gmail.com \\ ${ }^{2}$ Institute of Metal Physics, National Academy of Science, Kyiv, Ukraine, mvvmcv@gmail.com \\ ${ }^{3}$ Ivano-Frankivsk Scientific Research Forensic Center of the Ministry of Internal Affaris of Ukraine, Ivano-Frankivsk, \\ Ukraine, s.o.yuryev@gmail.com
}

\begin{abstract}
Alloys with general formula TiCo2-xSn $(0 \leq \mathrm{x} \leq 1.0)$ were produced by way of sintering primary components - pure metals in an argon atmosphere. The alloys were homogenized by annealing in the evacuated quartz vessel at $\mathrm{T}=1070 \mathrm{~K}$ during $500 \mathrm{~h}$. X-ray diffraction analysis confirmed single-phased condition of all samples.

Nuclear gamma resonance (NGR) analysis was made at $\mathrm{T}=295$ and $80 \mathrm{~K}$ using radiation source $\mathrm{BaSn}^{119} \mathrm{Sn}$. It was established, that $\mathrm{Sn}$ atoms in samples with $\mathrm{x}=0.6$ and 1.0 are in two crystallographic positions, pyramids (1) and tetrahedrons (2) to which isomer shifts correspond (relative to $\mathrm{SnO}_{2} 1.52-1.65 \mathrm{~mm} / \mathrm{s}$ for $\mathrm{Sn}(1)$ and $2.99 \mathrm{~mm} / \mathrm{s}$ for $\mathrm{Sn}(2)$. Zeeman splitting for $\mathrm{Sn}(1)$ in $\mathrm{TiCo}_{2} \mathrm{Sn}$ takes place at $\mathrm{T}=295$ and $80 \mathrm{~K}$, and for compositions with $\mathrm{x}=0.3-1.0$ at $\mathrm{T}=80 \mathrm{~K}$ only. For $\mathrm{Sn}(2)$ it is noted only in alloy TiCoSn at $\mathrm{T}=80 \mathrm{~K}$. The conclusion has been made on the reason of formation of effective magnetic fields on non-magnetic tin atoms nuclei.
\end{abstract}

Keywords: Heusler phases, nuclear gamma resonance, magnetic field, isomeric shift.

Received 9 October 2020; Accepted 15 December 2020.

\section{Introduction}

There are known works, for example [1], where the alloys $\mathrm{MeCO}_{2} \mathrm{Sn}(\mathrm{Me}=\mathrm{Ti}, \mathrm{Zr}$, Hf) have been studied using NGR method. Such alloys are attributed to Heusler phases whose magnetic and electric properties depend not only on the chemical nature of the element Me, but also on the degree of their lattice perfection $[2,3]$. As of today there is still no clear understanding of the mechanism of formation of magnetic superfine interactions for the non-magnetic $\mathrm{Sn}$ atom in $\mathrm{MeCo}_{2} \mathrm{Sn}$ phases. This is why investigation of magnetic fields on tin atoms nuclei in isostructural alloys with $\mathrm{MeCo}_{2} \mathrm{Sn}$ phase is important for resolving this problem.

This paper deals with the establishment of interrelation of the strength of magnetic field on tin atoms in solid solutions $\mathrm{TiCo}_{2-\mathrm{x}} \mathrm{Sn}$ and their composition and peculiarities of crystal structure.
It is known, that alloys $\mathrm{TiCo}_{2-\mathrm{x}} \mathrm{Sn}$ form solid solutions whose homogeneity includes values $\mathrm{x}=0.0 \ldots 1.0$ [4]. The alloy in this series - $\mathrm{TiCo}_{2} \mathrm{Sn}$ $(\mathrm{x}=0.0)$ is attributed to space group Fm3m [5]. Unit cell of $\mathrm{TiCO}_{2} \mathrm{Sn}$ it is shown in Fig. 1. Tin atoms in the structure of this alloy, we shall indicate them as $\operatorname{Sn}(1)$, form a dense cubic packing where tetrahedral and octahedral positions are filled by $\mathrm{Co}$ and $\mathrm{Ti}$ atoms respectively. The eight Co atoms are located in the first coordination sphere of $\operatorname{Sn}(1)$ atoms, in the second - six Ti atoms. X-ray diffraction analysis has shown, that TiCoSn alloy has a crystal structure that is a defective derivative of $\mathrm{TiCo}_{2} \mathrm{Sn}$ alloy structure where Co atoms occupy only half of tetrahedral positions $[6,7]$.

The other half of positions that are not filled by $\mathrm{Co}$ atoms forms tetrahedral vacancies in TiCoSn crystal lattice. However, as the results of precision X-ray diffraction analysis and the structure calculations, an excess over stoichiometric composition of $\mathrm{Co}$ and tin 


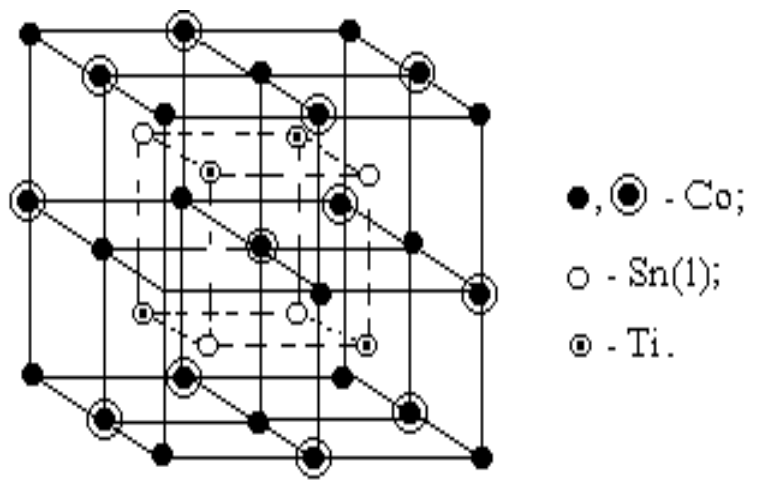

Fig. 1. Unit cell of $\mathrm{TiCo}_{2} \mathrm{Sn}$ alloy.

$(\operatorname{Sn}(2))$ atoms, each by 0.14 at. parts that are statistically distributed in the formed tetrahedral vacancies [3], indicated in Fig. 1 by large circles. This is why in TiCoSn alloy in the immediate surrounding of $\mathrm{Sn}(1)$ atom there are four Co atoms, located in the vertices of the tetragonal pyramid, and $\mathrm{Co}$ and $\mathrm{Sn}(2)$ atoms, statistically distributed in tetrahedral vacancies. At the same time, $\operatorname{Sn}(2)$ atoms have a cubic surrounding of four $\mathrm{Ti}$ atoms and four $\mathrm{Sn}(1)$ atoms.

\section{Preparation of samples, methods of investigations}

Samples of $\mathrm{TiCo}_{2-\mathrm{x}} \mathrm{Sn}$ alloys $(\mathrm{x}=0.0 ; 0.3 ; 0.6 ; 1.0)$ were produced by arcmelting of pure metals containing at least $99.99 \%$ of primary component in the atmosphere of purified argon. The alloys were homogenized by annealing in quarts vacuum vessels at $\mathrm{T}=1070 \mathrm{~K}$ during 500 yours. X-ray diffraction analysis has shown that all prepared samples were single-phased.

NGR spectra by spectrometer with uniform acceleration were measured. $\mathrm{BaSn}^{119} \mathrm{O}_{3}$ was used as the gamma-ray source at room temperature. The absorption spectra were obtained at temperatures $\mathrm{T}=295 \mathrm{~K}$ and $80 \mathrm{~K}$ on the samples that had natural concentration $\mathrm{Sn}^{119}$. Absorber thickness attained $0.1 \mathrm{mg} / \mathrm{cm}^{2}$ for $\mathrm{Sn}^{119}$.

\section{Results}

Fig. 2 and 3 show NGR-spectra of $\mathrm{TiCo}_{2-x} \mathrm{Sn}$ alloys $(\mathrm{x}=0.0 ; 0.3 ; 0.6 ; 1.0)$, and Table 1 shows results of calculations of their parameters. As follows from Fig. 2a, phase $\mathrm{TiCo}_{2} \mathrm{Sn}$ absorption spectrum at temperature $\mathrm{T}=295 \mathrm{~K}$ is characterized by a Zeeman structure. In the central part of the spectrum there is observed an overlapping of two separate resonance lines $A_{1}$ and $A_{2}$ with isomer shifts $\delta_{1}=1.14 \pm 0.02 \mathrm{~mm} / \mathrm{s}$ and $\delta_{2}=2.57 \pm 0.02 \mathrm{~mm} / \mathrm{s}$. As the calculations have shown, their intensities are practically the same and each attains of $7 \ldots 8 \%$ of total spectrum area.

Paramagnetic components in Fig. 2a result from the presence in the sample of tin atoms that did not enter $\mathrm{TiCo}_{2} \mathrm{Sn}$ phase. Measurement of NGR-spectra of $\mathrm{TiCo}_{2} \mathrm{Sn}$ at $\mathrm{T}=295 \mathrm{~K}$ in external field with induction
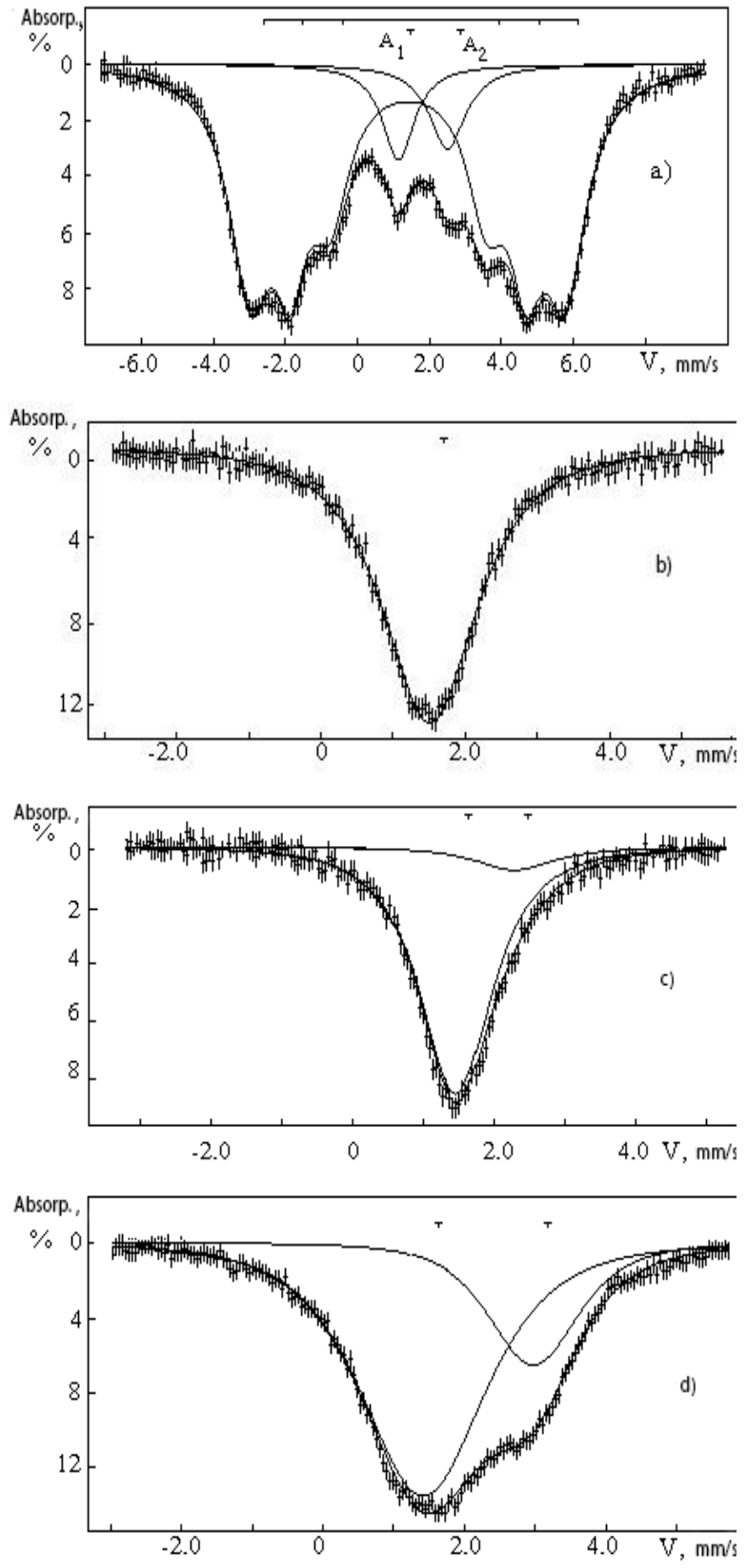

Fig. 2. NGR-spectra of $\mathrm{TiCo}_{2-\mathrm{x}} \mathrm{Sn}$ alloys at $\mathrm{T}=295 \mathrm{~K}$ : a) $\mathrm{TiCo}_{2} \mathrm{Sn}$; b) $\mathrm{TiCo}_{1,7} \mathrm{Sn}$; c) $\mathrm{TiCo}_{1,4} \mathrm{Sn}$; d) TiCoSn.

$\mathrm{B}=1.6 \mathrm{~T}$ has shown that the sign of the effective magnetic field $\mathrm{H}_{\text {eff }}$ on $\operatorname{Sn}(1)$ nuclei is positive, that is, its orientation coincides with orientation of $\mathrm{Co}$ atomic magnetic moments.

\section{III.Discussion of results}

In crystal structure of $\mathrm{TiCo}_{1.7} \mathrm{Sn}$ phase in comparison with $\mathrm{TiCO}_{2} \mathrm{Sn}$ there are absent about $15 \%$ of $\mathrm{Co}$ atoms which leads to the appearance of tetrahedral vacancies in $\mathrm{TiCo}_{1.7} \mathrm{Sn}$. NGR-spectrum of $\mathrm{TiCo}_{1.7} \mathrm{Sn}$ alloy at $\mathrm{T}=295 \mathrm{~K}$ has the look of a broadened $\left(\mathrm{G}_{1 / 2}=1.54 \pm 0.02 \mathrm{~mm} / \mathrm{s}\right) \quad$ single line (Fig. 2b). Broadening of the resonance line is, probably, connected with statistical distribution of the formed vacancies relative to $\mathrm{Sn}(1)$ atoms. At transition of alloy $\mathrm{TiCo}_{1.7} \mathrm{Sn}$ 
to $\mathrm{TiCo}_{1.4} \mathrm{Sn}$ the resonance spectrum of the latter (Fig. 2c) shows an additional line with a greater value of isomer shift (Table 1), that corresponds to tin atoms $\operatorname{Sn}(2)$

Let us turn our attention to the analysis of TiCoSn alloy absorption spectrum (Fig. 2d), in whose crystal structure there is absent already one half cobalt atoms. As it was mentioned above, $\operatorname{Sn}(1)$ atoms in this structure are located in the centers of pyramids formed by four atoms of cobalt, while the excessive atoms of tin $\operatorname{Sn}(2)$ and cobalt are located statistically in tetrahedral vacancies. In the result of overlapping of the lines of resonance absorption of gamma quanta by nuclei of $\mathrm{Sn}(1)$ and $\mathrm{Sn}(2)$ atoms a NGR-spectrum decomposed into two single lines was produced with the widths $\mathrm{G}_{1 / 2}=1.50 \pm 0.02 \mathrm{~mm} / \mathrm{s}$ characterized by different values of intensities and isomer shifts (Table 1). The greater value of isomer shifts for $\operatorname{Sn}(2)$ atoms compared to $\operatorname{Sn}(1)$ atoms testifies to the greater s-electron charges on $\operatorname{Sn}(2)$ nuclei which can be caused by the growth of chemical bonds covalence degree. As follows from our calculations, the number of $\mathrm{Sn}(1)$ atoms in $\mathrm{TiCoSn}$ is by 2.85 times greater than that of $\operatorname{Sn}(2)$ atoms.

As shown in [3], Curie temperature of alloys with $\mathrm{x}=0.0 ; 0.3 ; 0.6 ; 1.0$ attains $372,218,160$ and $135 \mathrm{~K}$ respectively. The Zeeman picture of NGR-spectra of $\mathrm{Sn}^{119}$ in $\mathrm{TiCo}_{2} \mathrm{Sn}$ is observed also at $\mathrm{T}=80 \mathrm{~K}$, and that for compounds with $\mathrm{x}=0.3 ; 0.6$ and 1.0 at $\mathrm{T}=80 \mathrm{~K}$ is shown in Fig. 3, which indicates presence of the effective magnetic fields on tin atoms and magnetic ordering of the alloys. It has been established, that at transition from compound with $\mathrm{x}=0.0$ to $\mathrm{x}=1.0$ mean values of the effective magnetic fields $\mathrm{H}_{\text {eff }}$ on $\mathrm{Sn}(1)$ nuclei change non-monotonically (Fig. 4). There is observed an increase of $\mathrm{H}_{\mathrm{ef}}$ values on sample with $\mathrm{x}=0.6$ in which are less magnetic Co atoms than in sample with $\mathrm{x}=0.3$. Such increase of $\mathrm{H}_{\mathrm{eff}}$ is congruent with the highest value on the effective magnetic field on Co atoms in the series of alloys $0.3 \leq \mathrm{x} \leq 1.0$ [3].

In test samples of $\mathrm{TiCo}_{2-x} \mathrm{Sn}$ alloys only cobalt atoms have a magnetic moment. Considering, that the distances between cobalt atoms in $\mathrm{TiCo}_{2-\mathrm{x}} \mathrm{Sn}(3.00 \AA \hat{)})$ exceed distances Co-Co in metal cobalt $(2.51 \AA$ Á), magnetic ordering in $\mathrm{TiCo}_{2-\mathrm{x}} \mathrm{Sn}$ alloys is evidently caused by indirect exchange interactions that have a long-range character. Such interactions may occur through polarization of conduction electrons and lead to emergence of the effective magnetic fields on tin nonmagnetic atom nuclei [8]. Positive sign $\mathrm{H}_{\text {eff }}$ on $\mathrm{Sn}^{119}$ nuclei in $\mathrm{TiCo}_{2} \mathrm{Sn}$ shows that spin density is formed by conduction electrons, most probably, in external s-shells often atoms.
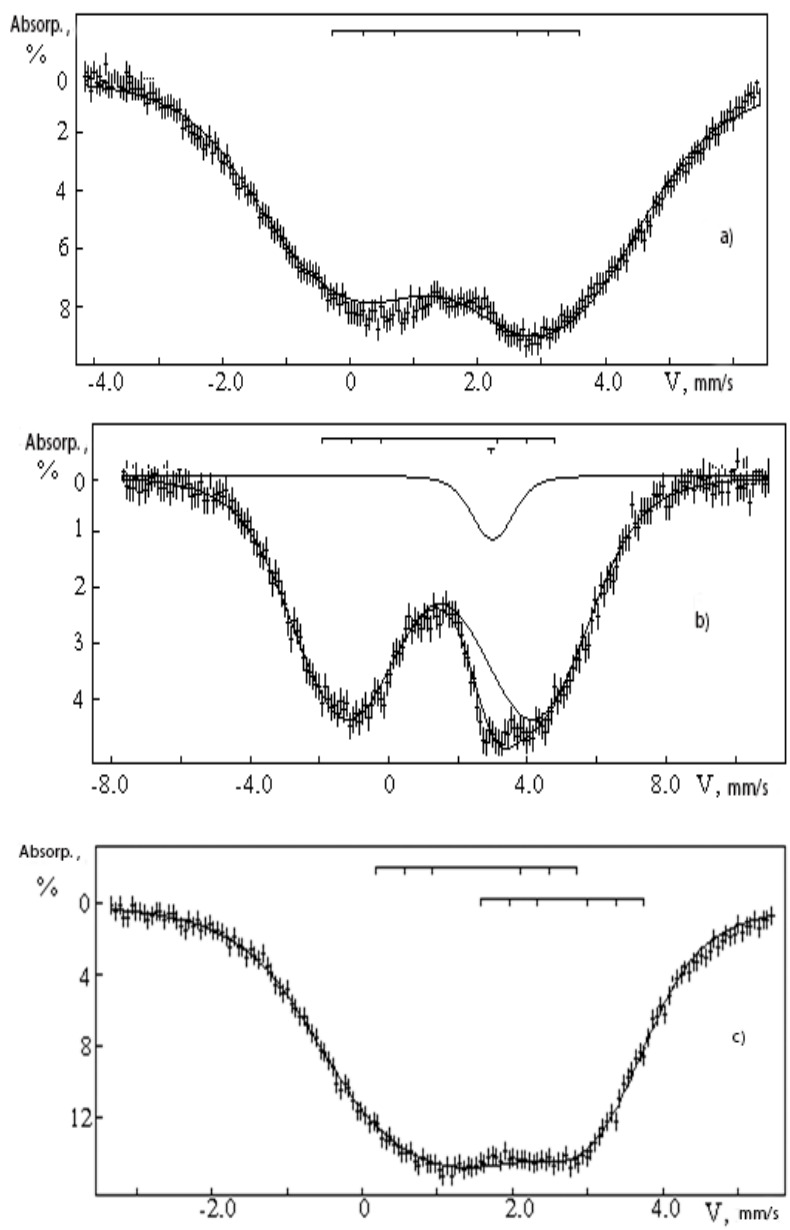

Fig. 3. NGR-spectra of $\mathrm{TiCo}_{2-\mathrm{x}} \mathrm{Sn}$ alloys at $\mathrm{T}=80 \mathrm{~K}$ : a) $\mathrm{TiCo}_{1,7} \mathrm{Sn}$; b) $\mathrm{TiCo}_{1,4} \mathrm{Sn}$; c) $\mathrm{TiCoSn}$.

As consistent with the results of our measurements, electric conductivity of alloys $\mathrm{TiCoSn}$ and $\mathrm{TiCo}_{2} \mathrm{Sn}$ is close. Assuming that concentration of conduction electrons in both alloys is also close, reduction of the number of $\mathrm{Co}$ atoms in $\mathrm{TiCoSn}$ compared to $\mathrm{TiCo}_{2} \mathrm{Sn}$ leads to redistribution of electrons between Co atoms and produces greater occupancy of $3 d$-zone in TiCoSn,

Table 1

$\mathrm{Sn}^{119}$ NGR-spectra parameters in $\mathrm{TiCo}_{2-\mathrm{x}} \mathrm{Sn}(\mathrm{x}=0.0 \ldots 1.0)$.

\begin{tabular}{|c|c|c|c|c|c|c|c|c|}
\hline \multirow{3}{*}{ Alloy } & \multicolumn{4}{|c|}{$\mathrm{T}=295 \mathrm{~K}$} & \multicolumn{4}{|c|}{$\mathrm{T}=80 \mathrm{~K}$} \\
\hline & \multicolumn{2}{|c|}{$\operatorname{Sn}(1)$} & \multicolumn{2}{|c|}{ Sn (2) } & \multicolumn{2}{|c|}{ Sn (1) } & \multicolumn{2}{|c|}{$\operatorname{Sn}(2)$} \\
\hline & $\delta, \mathrm{mm} / \mathrm{s}$ & $\mathrm{H}_{\mathrm{eff}}, \mathrm{kOe}$ & $\delta, \mathrm{mm} / \mathrm{s}$ & $\mathrm{H}_{\mathrm{eff}}, \mathrm{kOe}$ & $\delta, \mathrm{mm} / \mathrm{s}$ & $\mathrm{H}_{\mathrm{eff}}, \mathrm{kOe}$ & $\delta, \mathrm{mm} / \mathrm{s}$ & $\mathrm{H}_{\mathrm{eff}}, \mathrm{kOe}$ \\
\hline $\mathrm{TiCo}_{2} \mathrm{Sn}$ & $1.41(2)$ & $65 / 5$ & - & - & $1.44(3)$ & $82.2(5)$ & - & - \\
\hline $\mathrm{TiCo}_{1.7} \mathrm{Sn}$ & $1.51(3)$ & - & - & - & $1.48(2)$ & $28.1(5)$ & - & - \\
\hline $\mathrm{TiCo}_{1.4} \mathrm{Sn}$ & $1.46(2)$ & - & $2.61(3)$ & - & $1.52(3)$ & $50.6(5)$ & $2.99(3)$ & - \\
\hline TiCoSn & $1.46(2)$ & - & $2.97(2)$ & - & $1.56(3)$ & $19.9(5)$ & $2.99(4)$ & $15.6(8)$ \\
\hline
\end{tabular}

Isomer shifts $(\delta)$ were determined relative to $\mathrm{SnO}_{2}$. 


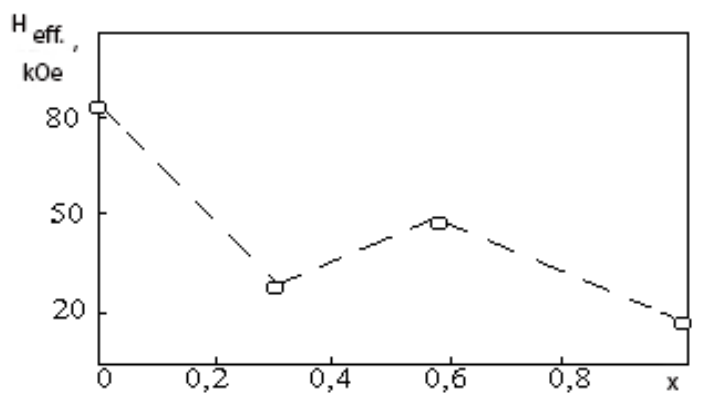

Fig. 4. Dependence of $\mathrm{H}_{\mathrm{eff}}$, on $\mathrm{Sn}(1)$ nuclei for $\mathrm{TiCo}_{2-\mathrm{x}} \mathrm{Sn}$ alloys at $\mathrm{T}=80 \mathrm{~K}$.

which determines reduction of $\mathrm{Co}$ atom magnetic moment [9]. Then presence of small values of magnetic fields on tin nuclei in TiCoSn compared to $\mathrm{TiCo}_{2} \mathrm{Sn}$ becomes understandable.

\section{Conclusions}

Two types of tin atoms Sn (1) and Sn (2) are found in $\mathrm{TiCo}_{2-\mathrm{x}} \mathrm{Sn}$ alloys $(\mathrm{x}=0.6$ and 1.0$)$, which are located in crystallographic pyramids and tetrahedral vacancies and which correspond to isomeric shifts of 1.52 $1.56 \mathrm{~mm} / \mathrm{s}$ and $2.99 \mathrm{~mm} / \mathrm{s}$. Higher isomeric shear value for $\mathrm{Sn}$ (2) atoms compared to $\mathrm{Sn}$ (1) atoms indicates higher charge density of s-electrons at Sn (2) nuclei, which may be caused by an increase in the covalence of chemical bonds. Magnetic ordering in $\mathrm{TiCo}_{2-x} \mathrm{Sn}$ alloys is associated with indirect exchange interactions through polarization of conduction electrons, which in turn lead to the appearance of $\mathrm{H}_{\mathrm{eff}}$ at the nuclei of non-magnetic tin atoms. A positive sign of $\mathrm{H}_{\mathrm{eff}}$ on the $\mathrm{Sn}$ nuclei in $\mathrm{TiCo}_{2-x} \mathrm{Sn}$ indicates that the spin density is generated by the conduction electrons in the outer shells of tin. Reduction of the number of Co atoms in $\mathrm{TiCoSn}$ in equation with $\mathrm{TiCo} 2 \mathrm{Sn}$ leads to the redistribution of electrons between Co atoms and creates the greater occupancy of the $3 d$ zone in TiCoSn.

Yuryev S.A. - PhD, Docent, Associate Professor of General Physics, Institute of Applied Mathematics and Basic Sciences;

Yushchuk S.I. - Professor, Doctor of Technical Sciences, Professor of the Department of General Physics, Institute of Applied Mathematics and Fundamental Sciences;

Moklyak V.V. - Doctor of Physical and Mathematical Sciences, Senior Research, Senior Research of Laboratory of Magnetic Film Physics;

Gonchar F.M. - PhD, Docent, Associate Professor of General Physics, Institute of Applied Mathematics and Basic Sciences;

Gorina O.M. - Candidate of Pedagogical Sciences, Associate Professor of the Department of General Physics of the Institute of Applied Mathematics and Basic Sciences;

Onyskiv B.B. - Master, Head of Sector.

[1] K. Endo, A. Shinogi, I. Vincze, J. Phyz. Soc. 40, 674 (1976) (DOI: 10.1103/PhysRevB.3.1637).

[2] Andrey Kosinsky, Ole Bjor Karsen, Magnus H. Sorby, Metallurgical and materials transactions E 3(4), 329 (2016) (DOI: 10.1007/s40553-016-0098-5).

[3] R.V. Skolozdra, Yu.V. Stadnyk, Yu.K. Horelenko, Ye.T. Terletskaya, Solid state physics 32, 2650 (1990).

[4] S.A. Yuryev, S.I. Yushchuk, R.V. Skolozdra, A.M. Horyn, Magnetic Materials and Application Conference EMMA'93 (KOSICE, 1993). P. 225.

[5] E. Uhl, Journ. Magnet and Magnetic Mater. 25(2), 221 (1981) (DOI: 10.1016/0304-8853(81)90123-2).

[6] S.I. Yushchuk, S.A. Yuryev, R.V. Skolozdra, Yu.V. Stadnyk, II Conference on nuclear-spectroscopic research of superfine interactions (Grozny, 1987). P. 47.

[7] Yu. Stadnyk, L. Romaka, A.M. Horyn, A. Tkachuk, P. Rogl, Journal of Alloys and Compounds 387, 251 (2005) (DOI: 10.1016/j.jallcom.2004.06.052).

[8] S.I. Yushchuk, S.A. Yuryev, V.A. Trukhtanov, Magnetic fields on atom in ferrites (Publishing house of National University "Lviv Plytechnic", Lviv, 2010).

[9] V.V. Chekin, Mössbauer spectroscopy of iron, gold and tin alloys (Publishing house Energoizdat, 1981). 


\title{
С.О. Юр'єв ${ }^{1}$, С.І. Ющук ${ }^{1}$, В.В. Мокляк ${ }^{2}$, Ф.М. Гончар ${ }^{1}$, О.М. Горіна ${ }^{1}$, Б.Б. Ониськів ${ }^{3}$
}

\section{Особливості кристалічної структури та надтонких взаємодій у сплавах Ti-Co-Sn}

\author{
${ }^{1}$ Наиіональний університет "Львівська політехніка", Львів, Украӥна, s.o.yигуеv@ gmail.com \\ ${ }^{2}$ Інститут фізики металів НАН України, Київ, Україна, тvvтсv@ gmail.com \\ ${ }^{3}$ Івано-Франківський науково-дослідний криміналістичний центр Міністерства внутрішніх справ Украӥни, \\ Івано-Франківськ, Украӥна, s.o.yигуеv@ gmail.com \\ Сплави із загальною формулою $\mathrm{TiCo}_{2}-\mathrm{XSn}$ отримували методом спікання первинних \\ компонентів - чистих металів в атмосфері аргону. Сплави гомогенізували відпалом у вакуумованій \\ кварцевій посудині при Т = 1070 К протягом 500 год. Рентгеноструктурний аналіз підтвердив однофазний \\ стан усіх зразків. Аналіз ядерного гамма-резонансу проводили при $\mathrm{T}=295$ та $80 \mathrm{~K} 3$ використанням \\ джерела випромінювання $\mathrm{BaSn}^{119} \mathrm{Sn}$. Встановлено, що атоми $\mathrm{Sn}$ у зразках $3 \mathrm{x}=0,6$ та 1,0 знаходяться у \\ двох кристалографічних положеннях, пірамідах (1) і тетраедрах (2), яким відповідають зсуви ізомерів \\ (щодо $\mathrm{SnO}_{2}$ 1,52 - 1,65 мм/с для $\mathrm{Sn}(1)$ і 2,99 мм/с для $\mathrm{Sn}(2)$. Розщеплення Зеемана для $\mathrm{Sn}(1)$ у $\mathrm{TiCo} 2 \mathrm{Sn}$ \\ відбувається при $\mathrm{T}=295$ і $80 \mathrm{~K}$, а також для композицій з х $=0,3-1,0$ при $\mathrm{T}=80 \mathrm{~K}$. Для $\operatorname{Sn}(2)$ \\ розщеплення Зеемана відзначається лише у сплаві TiCoSn при $\mathrm{T}=80 \mathrm{~K}$. Зроблено висновок щодо \\ утворення ефективних магнітних полів на немагнітних ядрах атомів олова.
}

Ключові слова: фази Гейслера, ядерний гамма-резонанс, магнітне поле, ізомерний зсув. 